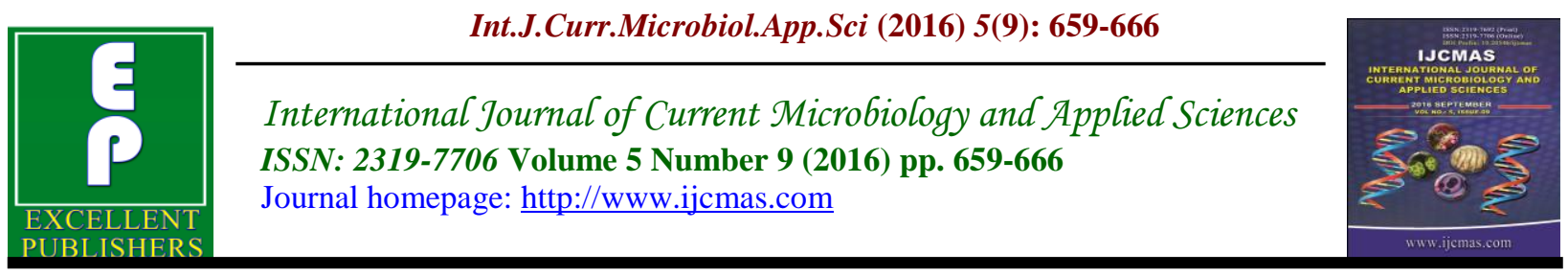

Original Research Article

http://dx.doi.org/10.20546/ijcmas.2016.509.076

\title{
Association of Arbuscular Mycorrhizal Fungi and other Rhizosphere Microbes with Different Medicinal Plants in the Calcareous Soil of Ariyalur District, India
}

\author{
M.P. Johnson and R. Stephan* \\ PG \& Research Department of Botany, Government Arts College \\ Ariyalur- 621713 , India \\ *Corresponding author
}

\begin{abstract}
A B S T R A C T
Keywords

Arbuscular mycorrhizal fungi,

Medicinal plants,

Microorganisms,

Rhizosphere,

Spore density.

Article Info

Accepted:

25 August 2016

Available Online:

10 September 2016

Presence of Arbuscular mycorrhizal fungi in the rhizosphere soil was investigated in different medicinal plants growing in calcareous soil conditions. Different medicinal plant species Gynandropsis pantaphylla L, Achyranthes aspera L., Cleome viscose L., Cassia obtuse Roxb., Catharanthus roseus L., Aristolochia indica L., Sphaeranthus indicus L., Spermacoce hispida L. Gymnema sylvestre R.BR. and Sesamum indicum L. were studied. The present study was carried out to study the interaction of different medicinal plants with AM fungi by spore population and root colonization. Huge variation was observed in the spore population and root colonization in spite of their growth in calcareous soil conditions. A great variation was observed in the bacterial and fungal population also.
\end{abstract}

\section{Introduction}

Indian is reticent source of medicinal and potential plants source and varieties of chemical substances. The narrow region of soil is directly influenced by root exudates used in rhizophere and associated soil micro organism. Recent studies have shown that, in natural ecosystems, plant diversity (Prober et al., 2015) and the genotypes of individual plants (Coats et al., 2014) can influence the composition of their rootassociated microbes. The term rhizosphere was related to the volume of soil affected by the presence and activity of the plant roots (Brimecombe Melissa et al., 2001).
In general root depositions are considered the major driving force behind plant microbe interactions in environment (Nelson and Louise, 2004; Pinton Roberto et al., 2001). Microbial activity is stimulated by these root depositions and in turn alters the rhizosphere soil.

The calcareous soil are highly complex ecological interactions are found in which the plant health and development (Jackson and Mason, 1984). Arbuscular mycorrhizae fungi varies with host ranges. Though they are ubiquitous, they show specificity in 
association with host plants. All the Arbuscular mycorrhizae species did not occur in all the areas and not all the species had the same effect on their symbiont (Dwivedi, 2015). Arbuscular mycorrhizae are important rhizosphere microorganisms. Arbuscular mycorrhizae clearly play an important role in terrestrial ecosystem, where they influence plant community structure and nutrient cycling (Jackson and Mason, 1984). Arbuscular mycorrhizal fungi are ubiquitous plant root symbionts that can be considered to be "keystone mutualists" in terrestrial ecosystem forming a link between biotic and abiotic ecosystem compounds via carbon and nutrient fluxes that pass between plant and fungi in the soil (O'Neill et al., 1991).

Arbuscular mycorrhizal fungi have been associated with medicinal plants (Gupta et al, 2009; Ram and Bhaduria, 2001). The study of rhizosphere microbes from the important medicinal plants is very crucial, as they are well known to have impact on plant growth and also produce industrially important metabolites and improve quality of medicinal product (Bafana and Lohiya, 2013). Cultivation of medicinal plants has a significant to study the commercial importance and their growth condition is gaining a lot of importance. Arbuscular mycorrhizae play a significant role in the growth and metabolism of the plants. In the present study medicinal plants and association of Arbuscular mycorrhizae harboring in their rhizosphere were collected in calcareous soil of Ariyalur district.

\section{Materials and Methods}

Rhizosphere soil samples and roots were collected from the experimental site in calcareous soil Ariyalur district. sample from each plant covering overall area of 50 $\mathrm{m}^{2}$ were collected randomly from $15 \mathrm{~cm}$ to $30 \mathrm{~cm}$ depth, later they were air dried and stored at $4^{\circ} \mathrm{C}$ for investigation. Three replicates of each composite sample were taken further analysis.

\section{Geographical location of experimental site}

The study area is in around the Ariyalur district in the state of Tamil Nadu (Latitude $11^{0} 8$ ' 14 'N $\mathrm{N}$; Longitude $79^{0} 4$ '40”E). Located in the middle of tamilnadu has a hot and dry climate. Summers start in April and it is peak in may with average high temperatures in the $\left(40^{\circ} \mathrm{C}\right)\left(100^{\circ} \mathrm{F}\right)$ range. A dry, mild winter starts in late December and lasts until early march. With little humidity average temperatures are in the $21-22^{\circ} \mathrm{C}(71-72)^{\circ} \mathrm{F}$ range.

Calcareous soils are relatively alkaline, in other words they have a high $\mathrm{pH}$. This is because of the very weak acidity of carbonic acid. They are characterized by the presence of calcium carbonate in the parent material and may have a calcic horizon, a layer of secondary accumulation of carbonates in excess of $15 \%$ calcium carbonate equivalent and at least 5\% more carbonate than an underlying layer.

\section{Isolation and identification of mycorrhizal fungal spores}

Collected 10 gram soil sample from each plant species were suspended in tap water and sieved using wet sieving and decanting method. Spore retained on the mesh were recovered by wash and then transferred to the Petridish, counted under Microscope. The spores were then identified by using key provided by (Schenck and perez, 1990).

\section{Estimation of arbuscular mycorrhizal colonization}

The cleand roots were cut into $1-\mathrm{cm}$ long pieces and stained with trypan blue, according to the procedure described by 
(Phillips and Hyman, 1970). The root were boiled in $10 \% \mathrm{KOH}$ for $15 \mathrm{~min}$. and stained with $0.08 \%$ trypan blue. The mycorrhizal colonization (mycelium, arbuscules and vesicles) was observed in each segment under stage microscope. The percentage of colonization was calculated using the formula.

Percentage of root infection $=$ No. of root segments infected / Total root segments observed X100

\section{Soil parameters}

Soil $\mathrm{pH}$ was determined using electronic $\mathrm{pH}$ meter by mixing the soil in distilled water in 1:2 ratio. Moisture percentage of soil was determined by taking $100 \mathrm{~g}$ soil. Soil sample was freshly weighed and dried using microwave oven at $150^{\circ} \mathrm{C}$ for $5 \mathrm{~min}$. allowed to cool and weighed again for loss weight on drying. The moisture percentage was determined by using the formula:

Moisture percentage $(\%)=$ Initial weight $/$ weight after drying X100

Other parameter like $\mathrm{pH}$, Moisture content, E.C, percentage of organic carbon, Total Phosphorus (ppm), Total potassium $(\mathrm{kg} / \mathrm{H})$, Available Nitrogen (g/100g) (micro- Kg) were also calculated.

\section{Microbial population on nutrient agar and Asthana Hakers medium}

Bacterial and fungi population from the rhizosphere soil was enumerated by serial dilution and plate count technique using Nutrient Agar and Asthana-Hakers media. The bacterial population was expressed in terms of colony forming units (CFU).

CFU per gm soil $=$ No. of colonies per plate $\mathrm{X}$ dilution factor /Dry. Weights of soil. This isolated fungi were identified till the species level was based on colony morphology by using standard manual. The qualitative enumeration was expressed as frequency occurrence of fungal sp.

\section{Statistical analysis}

All the statistical values are concurrent at $\alpha$ $=5 \%$.

\section{Results and Discussion}

Arbuscular mycorrizal fungi (AMF) are important microbes in rhizosphere soil. Most plant species are typically mycorrhizal with approximately four-fifth of all land plants form AM fungal Association (Minz Dror and Maya Ofek, 2011). The presence of AMF will influence the plant growth and development. An effort was made to draw a relation between some different medicinal plants and their respective AM fungal population.

In the present study, all ten different medicinal plant species were found infected with AM fungi. Various workers (Gupta et al., 2009). showed the AM fungal infection in medicinal plants, though they were different plant species. Some medicinal plants that were used in this study are: Gynandropsis pantaphylla L, Achyranthes aspera L., Cleome viscose L., Cassia obtuse Roxb., Catharanthus roseus L., Aristolochia indica L., Sphaeranthus indicus L., Spermacoce hispida L. Gymnema sylvestre R.BR. Sesamum indicum $L$

Variation in number of AM fungal spores in plants is recorded as shown in (Table-1). The mean spore population was recorded viz. Gynandropsis pantaphylla was 46.63. Achyranthes aspera, was 62.12 and Cleome viscose was 60.53 AM fungal spores were observed. Cassia obtuse, spore population was 34.37, Catharanthus roseus, the mean 
spore count was 35.21, Aristolochia indica, the average spores were 34.12 and Sphaeranthus indicus, 22.31 spore were identified. Spermacoce hispida had 47.12 as average no. of spore and Gymnema sylvestre has shown 23.14 mean spore. In Sesamum indicum in maximum spore shown as 88.34 in their rhizospere soil respectively.

The percentage of AM colonization in different medicinal plants the highest colonization was obtained in Catharanthus roseus 95\%(Fig- A), Gymnema sylvestre R.BR. 80\%(Fig- B), Spermacoce hispida L 70\%(Fig- C), Sesamum indicum L. 66\% (Fig- D).

\section{Soil Parameters}

The Soil sample are analyzed using the following the standard procedures for $\mathrm{pH}$, moisture, nitrogen (Subbaiah and Asija, 1956), phosphorus and potassium, Jackson (1973). Spores were identified using a manual (Schenck and Perez, 1990). Moisture of soil sample was found be 49.6 . E.C. of the soil was found to be $0.916 \mathrm{Sm}^{-1}$ the total organic carbon of the soil sample was 0.24; Total Phosphorus, total potassium and available nitrogen were found to be $62.71 \mathrm{ppm}, \quad 298 \mathrm{~kg} / \mathrm{ha}$ and $0.69 \mathrm{~g} / 100 \mathrm{~g}$ respectively. Result of biochemical analysis of soil is shown in (Table 3 ).

Table.1 Mean spore population in the rhizosphere of different medicinal plants

\begin{tabular}{|c|l|c|c|}
\hline S.No & \multicolumn{1}{|c|}{ Name of the plant } & Family Name & Mean spore count/100g \\
\hline 1 & Gynandropsis pantaphylla L. & Capparidaceae & 46.63 \\
\hline 2 & Achyranthes aspera L. & Amaranthaceae & 62.12 \\
\hline 3 & Cleome viscose L. & Capparidaceae & 60.53 \\
\hline 4 & Cassia obtuse Roxb. & Caesalpiniaceae & 34.37 \\
\hline 5 & Catharanthus roseus L. & Apocynaceae & 35.21 \\
\hline 6 & Aristolochia indica L. & Aristolochiaceae & 34.12 \\
\hline 7 & Sphaeranthus indicus L. & Asteraceae & 22.31 \\
\hline 8 & Spermacoce hispida $L$. & Rubiaceae & 47.12 \\
\hline 9 & Gymnema sylvestre R.BR. & Asclepiadaceae & 23.14 \\
\hline 10 & Sesamum indicum L. & Pedaliaceae & 88.34 \\
\hline
\end{tabular}

Table.2 Percentage of AM colonization in different medicinal plants

\begin{tabular}{|c|l|c|c|c|c|}
\hline S.No & Medicinal plant & \% of Colonization & \multicolumn{3}{l|}{ Type of infection } \\
\hline & & & M & V & A \\
\hline 1 & Gynandropsis pantaphylla L. & 25 & + & - & - \\
\hline 2 & Achyranthes aspera L. & 30 & + & - & + \\
\hline 3 & Cleome viscose L. & 40 & + & - & + \\
\hline 4 & Cassia obtuse Roxb. & 50 & + & - & - \\
\hline 5 & Catharanthus roseus L. & 95 & + & + & + \\
\hline 6 & Aristolochia indica L. & 60 & - & - & - \\
\hline 7 & Sphaeranthus indicus L. & 27 & + & - & - \\
\hline 8 & Spermacoce hispida L. & 70 & + & - & - \\
\hline 9 & Gymnema sylvestre R.BR. & 80 & + & - & + \\
\hline 10 & Sesamum indicum L. & 66 & + & - & - \\
\hline
\end{tabular}


Table.3 Physico - chemical Characterstic of Rhizosphere soil

\begin{tabular}{|c|c|c|}
\hline S.No & \multicolumn{2}{|c|}{ Physico-chemical Character } \\
\hline 1 & $\mathrm{pH}$ & 7.5 \\
\hline 2 & Moisture content & 49.6 \\
\hline 3 & E.C & 0.916 \\
\hline 4 & \% of Organic Carbon & 0.24 \\
\hline 5 & Total $\mathrm{P}(\mathrm{ppm})$ & 62.71 \\
\hline 6 & Total K $(\mathrm{Kg} / \mathrm{Ha})$ & 298 \\
\hline 7 & Avilable Nitrogen $(\mathrm{g} / 100 \mathrm{~g})$ & 0.69 \\
\hline
\end{tabular}

Table.4 Total Bacterial count in the rhizosphere of different medicinal plants

\begin{tabular}{|c|l|c|}
\hline S.No & \multicolumn{1}{|c|}{ Medicinal plant } & Bacterial Population @ (106) in CFU \\
\hline 1 & Gynandropsis pantaphylla L. & 21 \\
\hline 2 & Achyranthes aspera L. & 10 \\
\hline 3 & Cleome viscose L. & 22 \\
\hline 4 & Cassia obtuse Roxb. & 20 \\
\hline 5 & Catharanthus roseus $L$. & 24 \\
\hline 6 & Aristolochia indica L. & 12 \\
\hline 7 & Sphaeranthus indicus $L$. & 24 \\
\hline 8 & Spermacoce hispida L. & 17 \\
\hline 9 & Gymnema sylvestre R.BR. & 12 \\
\hline 10 & Sesamum indicum L. & S \\
\hline
\end{tabular}

The data summarized in table- 4 show bacterial population of rhizosphere soil of some medicinal plants.

Table.5 Fungal biodiversity in the rhizosphere of different medicinal plants

\begin{tabular}{|l|l|l|}
\hline S.No & Medicinal plant & Fungi (105) \\
\hline 1 & Gynandropsis pantaphylla L. & $\begin{array}{l}\text { Alterneria, Aspergillus, Penicillium, Trichoderma } \\
\text { viride }\end{array}$ \\
\hline 2 & Achyranthes aspera L. & Alterneria, Aspergillus, Cladosporium, Fusarium \\
\hline 3 & Cleome viscose L. & Aspergillus, Fusarium, Penicillium, Trichoderma viride, \\
\hline 4 & Cassia obtuse Roxb. & Alterneria, Aspergillus, Cladosporium Penicillium, \\
\hline 5 & Catharanthus roseus L. & Alterneria, Aspergillus, Penicillium, Trichoderma viride \\
\hline 6 & Aristolochia indica L. & $\begin{array}{l}\text { Alterneria, Aspergillus, , Cladosporium,Trichoderma } \\
\text { viride }\end{array}$ \\
\hline 7 & Sphaeranthus indicus L. & Alterneria, Aspergillus, Fusarium, Trichoderma viride \\
\hline 8 & Spermacoce hispida L. & $\begin{array}{l}\text { Alterneria, Cladosporium, Penicillium, Trichoderma } \\
\text { viride }\end{array}$ \\
\hline 9 & Gymnema sylvestre R.BR. & Alterneria, Aspergillus, Penicillium, Trichoderma viride \\
\hline 10 & Sesamum indicum L. & Alterneria, Fusarium, Penicillium, Trichoderma viride \\
\hline
\end{tabular}




\section{Fig.1}

A



$\mathrm{C}$

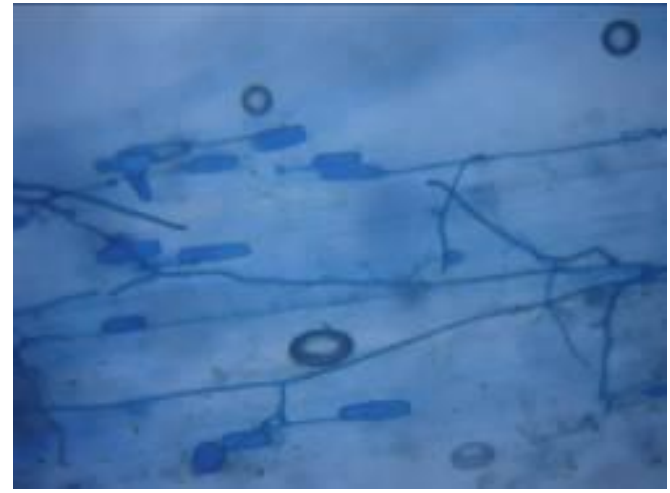

B

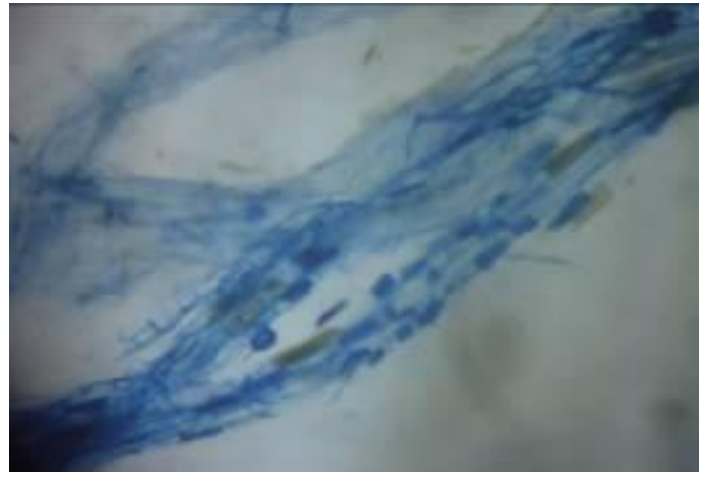

$\mathrm{D}$

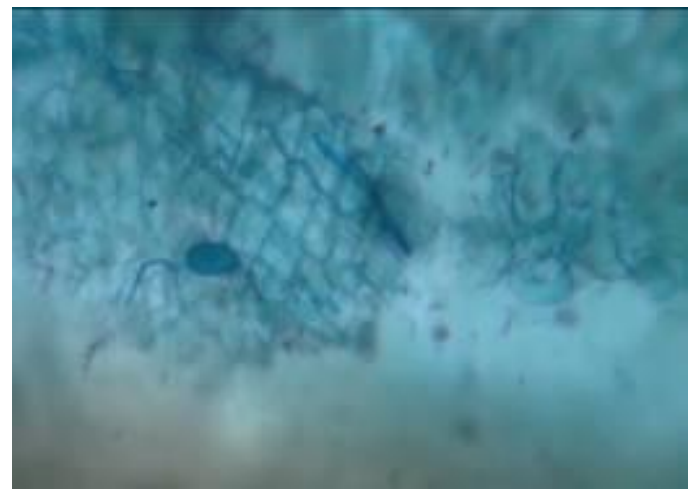

Arbuscular mycorrizal (AM) Colonization in the medicinal plants roots (X100 -view)

A. Catharanthus roseus L.,

B. Gymnema sylvestre R.BR.

C. Spermacoce hispida L.

D. Sesamum indicum $L$.

The data summarized in table 4 shows bacterial population of rhizosphere soil of ten different plants. The microbial population of Aristolochia indica, Spermacoce hispida 24X $10^{6} \mathrm{CFU}$, Cassia obtuse $22 \times 10^{6} \mathrm{CFU}$, Achyranthes aspera had 21 X $10^{6}$ CFU, Gynandropsis pantaphylla, Cleome viscose, Catharanthus roseus, Sphaeranthus indicus, Gymnema sylvestre, Sesamum indicum $8 \times 10^{6} \mathrm{CFU}$, $10 \times 10^{6} \mathrm{CFU}, 20 \times 10^{6} \mathrm{CFU}, 12 \times 10^{6}$ $\mathrm{CFU}, 17 \mathrm{X} 10^{6} \mathrm{CFU}, 12 \mathrm{X} 10^{6} \mathrm{CFU}$ respectively.

The fungal population of the rhizospere calcareous soil was showing Alterneria species, Aspergillus species. Penicillium species, Fusarium species, Cladosporium species and Trichoderma viride species. The (Table- 5) shows the major fungal species dominant in rhizosphere of each plant. Gynandropsis pantaphylla was found to be associated with Alterneria, Aspergillus, Penicillium and Trichoderma viride; Achyranthes aspera was associated with the fungal genera Alterneria, Aspergillus, Cladosporium and Fusarium; Cleome viscose was found to be associated with Aspergillus, Fusarium, Penicillium and Trichoderma viride; Cassia obtuse was associated with Alterneria, Aspergillus, Cladosporium and Penicillium; 
Catharanthus roseus was associated with Alterneria, Aspergillus, Penicillium and Trichoderma viride ; Aristolochia indica with Alterneria, Aspergillus,, Cladosporium and Trichoderma viride ; Sphaeranthus indicus was found to be associated with Alterneria, Aspergillus, Fusarium and Trichoderma viride; Spermacoce hispida was associated with Alterneria, Cladosporium, Penicillium and Trichoderma viride; Gymnema sylvestre was found to be associated with Alterneria, Aspergillus, Penicillium and Trichoderma viride ; Sesamum indicum was associated with Alterneria, Fusarium, Penicillium and Trichoderma viride. The author's findings also support this and are incorporated by the findings of (Manoharachary et al., 1998).

Most plant species are typically mycorrhizal with approximately four-fifth all land plants from AM fungal association. In the present study, different medicinal plants species were found infected with AM fungi. Arbuscular mycorrhizal fungi (AM) are associated with almost all the plants in nature (Hayman, 1982) Various worker showed the AM fungal infection in medicinal plants, through they were different plant spsecies. The present study regarding AM fungal colonization of some medicinal plants has shown that highest number of spores is associated in the rhizosphere of Catharanthus roseus $\mathrm{L}$. highest percentage of root colonization (95\%) was also found in Catharanthus roseus the infection included : vesicles, Arbuscules and mycelium. This may be due to the root exudates available in the rhizosphere soil of Catharanthus roseus $L$. that might have stimulated the AM spores to germinate and infect. Bacterial and fungal population was also found to be extensive in these medicinal plants. From the above analysis it was found that medicinal plants harbor AM fungi and other microbes and there is a prominent difference in microbial load of different rhizosphere soils. However, an extensive research has to be done in this field in relation to the medicinal plants and their interaction with rhizosphere soil and microorganaisms.

\section{References}

Bafana, A., Lohiya, R. 2013. Diversity and metabolic potential of culturable rootassociated bacteria from Origanum vulgare in sub-Himalayan region. World J. Microbiol. Biotechnol., 29: 63-74.

Brimecombe Melissa, J., Frans, A., De Leij and James, M., Lynch. 2001. The effect of root exudates on rhizosphere microbial populations, The Rhizosphere, Marcel Dekker, New York, 95- 140.

Coats, V.C., Pelletreau, K.N., Rumpho, M.E. 2014. Amplicon pyrosequencing reveals the soil microbial diversity associated with invasive Japanese barberry (Berberis thunbergii DC.). Mol. Ecol., 23: 1318-32.

Dwivedi, O.P. 2015. Distribution and association of AMF in different cultivars of wheat from lalganj pratapgarh district of UP, india. $A d v$. Biosci. Biotechnol., 6: 353-357.

Gupta, A.K., Chaturvedi, S. and Sharma, A.K. 2009. Arbuscular mycorrhizal fungal diversity in some medicinal plans, Mycorrhiza News, 20(4): 10-13.

Hayman, D.S. 1982. Practical aspects of vesicular arbuscular mycorrhizal. In: Adv. Agri. Microbiol., edited by Subba Rao N.S. New Delhi, Oxford IBA 325- 373.

Jackson, M.L. 1973. Soil Chemical Analysis, New Delhi, Prentice Hall, India. 
Jackson, R.M. and Mason, P.A. 1984. Mycorrhiza, Edward Arnold Ltd., London, UK.

Manoharachary, C., Varma, A. and Reddy, P.J.M. 1998. Application of AM fungi in oil seed production. In: Microbes for health, wealth and sustainable environment (Ed., Ajit Varma). Malhotra publishing house, New Delhi 129-135.

Minz Dror and Maya Ofek. 2011. Rhizosphere Microorganisms, Beneficial Microorganisms in Multicellular Life Forms, 105-121.

Nelson, Louise, M. 2004. Plant growth promoting rhizobacteria (PGPR): Prospects for new inoculants, Online Crop Manage., 1094.

O’Neill, E.G., O'Neill, R.V. and Norby, R.J. 1991. Hierarchy theory as a guide to mycorrhizal research on large- scale problems, Environ. Pollu., 73: 271284.

Philips, J.M. and Hyman, D.S. 1970. Improved procedures for clearing roots and staining parasitic and VAM fungi for rapid assessment of infection, Transactions of the British Mycol. Soc., 55: 158-161.
Pinton Roberto, Zeno Varanini and Paolo Nannipieri. 2001. The rhizosphere as a site of biochemical interactions among soil components, plants and microorganisms, The Rhizosphere, New York, Marcel Dekker, 1-17.

Prober, S.M., Leff, J.W., Bates, S.T., Borer, E.T., Firn, J., Harpole, W.S. 2015. Plant diversity predicts beta but not alpha diversity of soil microbes across grasslands worldwide. Ecol. Lett., 18: 85-95.

Ram, V. and Bhaduria, S. 2001. Vesicular arbuscular mycorrhizal association with some medicinal plants growing on alkaline soils of Mainpuri district, Uttar Pradesh, Myorrhiza News, 13(2): 12-14.

Schenck, N.C. and Perez, Y. 1990. Manual for the identification of vesicular arbuscular mycorrhizal fungi Synergistic Publications: Gainesville, FL., U.S.A. 1-286.

Subbaiah, B.V., Asija, G.L. 1956. A rapid procedure for the estimation of available nitrogen in soils. Curr. Sci., 25: 259-260.

\section{How to cite this article:}

Johnson, M.P., and Stephan, R. 2016. Association of Arbuscular Mycorrhizal Fungi and other Rhizosphere Microbes with Different Medicinal Plants in the Calcareous Soil of Ariyalur District, India. Int.J.Curr.Microbiol.App.Sci. 5(9): 659-666.

doi: http://dx.doi.org/10.20546/ijcmas.2016.509.076 